\title{
Predictors of Complex Aortic Plaques in Patients Undergoing Transoesophageal Echocardiography
}

\author{
Transözefajiyal Ekokardiyografik İnceleme Yapılan Hastalarda Kompleks Aort \\ Plaklarının Öngördürücüleri
}

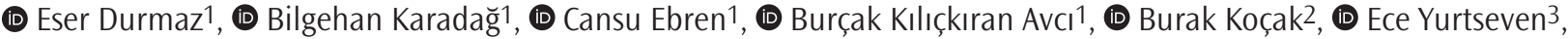 \\ (1) Damla Koca1 ${ }^{1}$ (1) Utku Raimoğlu1, (1) Mehmet Semih Belpınar1, (1) Zeki Öngen1
}

\begin{abstract}
${ }^{1}$ istanbul University-Cerrahpașa, Cerrahpaşa Faculty of Medicine, Department of Cardiology, İstanbul, Turkey
2University of Health Sciences Turkey, İstanbul Training and Research Hospital, Clinic of Radiology, İstanbul, Turkey

${ }^{3}$ Koç University Hospital, Clinic of Cardiology, İstanbul, Turkey
\end{abstract}

\begin{abstract}
Introduction: Atrial fibrillation (AF) is one of the most important causes of ischaemic stroke according to the TOAST classification. The $\mathrm{CHA}_{2} \mathrm{DS}_{2}$-VASC score is a widely used scoring system for estimating systemic thromboembolism in patients with non-valvular AF. TOAST classification indicates that an ischaemic stroke may also be due to large artery atherosclerosis. since some of the atherosclerotic risk factors also occur in the $\mathrm{CHA}_{2} \mathrm{DS}_{2}-\mathrm{VASC}$ scoring system, we hypothesised that this scoring system can also predict the presence of complex aortic plaques and their stroke risk.
\end{abstract}

Methods: We retrospectively investigated 551 patients who underwent transthoracic echocardiography and subsequent transoesophageal echocardiography (TEE). Baseline characteristics of the patients were recorded, and the $\mathrm{CHA}_{2} \mathrm{DS}_{2}$ VASC score was calculated before the TEE examination. Aortic plaques are classified as complex when they are protruding more than $4 \mathrm{~mm}$, mobile or have irregular boundaries.

Results: Among 551 patients, 110 complex aortic plaques (CAPs) were detected. Considering all the patients, higher $\mathrm{CHA}_{2} \mathrm{DS}_{2}$ VASc score [odds ratio (OR): 2.905], increasing age (OR: 1.056), and male (OR: 3.008) were significantly associated with CAP. $\mathrm{CHA}_{2} \mathrm{DS}_{2}$-VASc score was even more significantly associated with CAP in patients with a previous stroke $[\mathrm{p}<0.001,0 \mathrm{R}: 16.754$ (4.196-66.894), confidence interval (Cl): 95\%]. After excluding complicated aortic plaques from the calculation, higher $\mathrm{CHA}_{2} \mathrm{DS}_{2}$-VASC score in patients with AF was also associated with the presence of CAPs ( $p<0.001$, OR: 3.379 1.848-6.179, Cl: 95\%).

Conclusion: Although the $\mathrm{CHA}_{2} \mathrm{DS}$-VASC score has been validated to estimate thromboembolic risk in patients with non-valvular AF, the results of this study show that a high CHA DS -VASC score may also indicate an increased risk for CAP in patients with both sinus and non-valvular-AF rhythm.

Keywords: Complex aortic plaques, $\mathrm{CHA}_{2} \mathrm{DS}_{2}$-VASc score, ischaemic stroke

\section{öz}

Amaç: Atriyal fibrilasyon (AF) TOAST sınıflamasına göre iskemik inmenin önemli bir nedenidir. $\mathrm{CHA}_{2} \mathrm{DS}_{2}$-VASC skor non-valvüler AF'li hastalarda iskemik stroke ve tromboemboli riskini belirlemek için sıklıkla kullanılan bir skorlama sistemidir. Bunun yanı sıra TOAST sınıflamasında, büyük arter aterosklerozu kardiyoembolizm gibi iskemik inmenin ayrı bir sınıfıdır. Biz bu çalışmamızda $\mathrm{CHA}_{2} \mathrm{DS}_{2}$-VASc skorunun kompleks aortik plaklar (KAP) ile olan ilişkisini incelemeyi amaçladık.

Yöntemler: Retrospektif olarak transtorasik ve sonrasında transözefajiyal ekokardiyografi (TÖE) uygulanmış 551 hasta analiz edildi. Hastaların demografik ve klinik özellikleri kaydedildi. $\mathrm{CHA}_{2} \mathrm{DS}_{2}$-VASC skoru TÖE incelemesi öncesinde hesaplandı. 4 mm'den büyük, hareket eden veya düzensiz sınırları olan plaklar KAP olarak kabul edildi.

Bulgular: Beş yüz elli bir hasta dahil edildi ve $110 \mathrm{KAP}$ saptandı. Tüm hastalar göz önüne alındığında $\mathrm{CHA}_{2} \mathrm{DS}_{2}$-VASC skoru [olasılık oranı (OR): 2,905], yaş (OR: 1,056) ve ve erkek cinsiyet (OR: 3,008) anlamlı bir șekilde KAP ile ilișkili saptandı. Buna ek olarak daha önce iskemik inme geçiren $[p<0,001$, OR: 16,754 (4,196-66,894), güven aralığı (GA) \%95] veya AF'li hastalarda da ( $p<0,001$, OR: 3,379 1,848-6,179, GA: \%95) KAP $\mathrm{CHA}_{2} \mathrm{DS}_{2}$-VASC skoru ile ilişkili saptandı.

Sonuç: Her ne kadar CHA2DS2-VASc skoru non-valvüler AF hastalarında tromboembolik riski hesaplamak için geliștirilmiş olsa da, bu çalıșmanın sonucu CHA2DS2-VASc skorunun hem sinüs hem de AF ritmindeki hastalarda artmış KAP riskine işaret edeceğini de göstermiștir.

Anahtar Kelimeler: Kompleks aort plakları, $\mathrm{CHA}_{2} \mathrm{DS}_{2}$-VASC skoru, iskemik inme

Presented in: This study has been presented in the 2017 European Society of Cardiology congress.

Address for Correspondence/Yazıșma Adresi: Eser Durmaz MD, İstanbul University-Cerrahpașa, Cerrahpașa Faculty of Medicine, Department of Cardiology, İstanbul, Turkey

Phone: +90 5337737121 E-mail: durmazeser@hotmail.com ORCID ID: orcid.org/0000-0002-1468-0153

Received/Geliș Tarihi: 26.06.2020

Cite this article as/Atıf: Durmaz E, Karadağ B, Ebren C, Kılıçkıran Avcı B, Koçak B, Yurtseven E, Koca D, Raimoğlu

U, Belpınar MS, Öngen Z. Predictors of Complex Aortic Plaques in Patients Undergoing Transoesophageal

Echocardiography. İstanbul Med J 2020; 21(6): 436-442.

(C) Copyright 2020 by the University of Health Sciences Turkey, Istanbul Training and Research Hospital/Istanbul Medical Journal published by Galenos Publishing House

(C) Telif Hakkı 2020 Sağıı Bilimleri Üniversitesi Istanbul Ĕgitim ve Araştırma Hastanesi/Istanbul Tıp Dergisi, Galenos Yayınevi tarafından basılmıștır. 


\section{Introduction}

Ischaemic stroke is one of the leading causes of mortality and morbidity worldwide and it is related to multiple underlying aetiologies. Although the trial of ORG 10172 in acute stroke treatment (TOAST) ischaemic stroke classification has divided ischaemic strokes into five subgroups according to the underlying aetiology, the underlying aetiologies cannot be definitely diagnosed in the majority of the cases (1).

Cardioembolism is assumed to be the underlying cause in 30\% of ischaemic strokes. Previous studies have demonstrated that the $\mathrm{CHA}_{2} \mathrm{DS}_{2}$-VASC score predicts cardioembolic stroke particularly in patients with non-valvular atrial fibrillation (NV-AF). Moreover, some studies suggested that it might also predict stroke risk even in patients with sinus rhythm (2-4). Current literature suggests that an increment in the $\mathrm{CHA}_{2} \mathrm{DS}_{2}$-VASc score is related to a higher stroke risk due to left atrial (LA) abnormalities, which create a favourable milieu for thrombus formation (5). Most of the risk factors that make up the $\mathrm{CHA}_{2}$ DS - -VASC score are also traditional risk factors for atherosclerosis; therefore, an increased $\mathrm{CHA}_{2} \mathrm{DS}_{2}$-VASC score may also imply a higher atherosclerotic burden. Overwhelming evidence in the literature suggests that the presence of aortic atheroma plaques predicts future ischaemic stroke, especially when the thickness exceeds $4 \mathrm{~mm}$. Sugioka et al. (6) have demonstrated a significant relationship between $\mathrm{CHADS}_{2}$ score and complex aortic plaques (CAP). Since the $\mathrm{CHA}_{2} \mathrm{DS}_{2}$-VASC score predicts ischaemic stroke modestly better than the CHADS score (1), regardless of the underlying rhythm, we aimed to investigate the relationship between the $\mathrm{CHA}_{2} \mathrm{DS}_{2}$ VASC score and CAP.

\section{Methods}

\section{Study Population}

We retrospectively analysed 651 patients who underwent transoesophageal echocardiography (TEE) between January 2016 and January 2018 in our university clinic. Twenty-one patients were excluded due to the lack of prior transthoracic echocardiographic (TTE) data and 79 patients were excluded due to the absence of clinical variables. Finally, 551 patients (267 men and 284 women) were included in the analysis. The study protocol was approved by the Istanbul UniversityCerrahpaşa, Cerrahpaşa Faculty of Medicine Ethics Committee (decision no: 51436, date: 07.02.2018) and patients were included after their informed consent was obtained.

Patients' demographic characteristics such as age, sex and medical history including diabetes mellitus (DM), hypertension (HT), coronary artery disease (CAD), peripheral arterial disease, ischaemic stroke and AF were recorded.

$\mathrm{CHA}_{2} \mathrm{DS}_{2}$-VASC score was calculated according to the recommendations of the current guidelines. In brief, one point was given for the history of heart failure, presence of diabetes, HT, age between 65 and 75 years, female sex, vascular disease and two points for age $>75$ years and history of previous stroke. History of myocardial infarction, symptomatic peripheral arterial disease and the presence of CAPs were considered to be vascular diseases as recommended.

\section{Echocardiographic Data}

TTE was performed prior to the TEE examination of each patient in accordance with the American Society of Echocardiography and
European Association of Cardiovascular Imaging guidelines. TEE was performed for various clinical indications such as infective endocarditis, assessment of valvular diseases or identification of the aetiology of an ischaemic stroke. TTE and TEE findings that were suggested as potential sources of cardioembolism according to the TOAST classification were collected. In the TOAST trial, cardiac abnormalities, which are prone to be the source of embolism, were divided into two groups: high risk and medium risk.

TEE was performed to all the patients using a commercially available ultrasound imaging system with a 3-D matrix array transoesophageal transducer (Philips Medical systems, IE33, Andover, MA, USA and probe X7-2t). The thoracic aorta was screened when the probe was withdrawn gradually from the descending aorta after the routine assessment of the cardiac structures. Aortic plaques were considered complex if the plaque protruded more than $4 \mathrm{~mm}$ from intima to the lumen in the horizontal plane and perpendicular to the arterial wall. We also considered plaques as complex if the plaque had a mobile component or an ulceration. Plaque ulceration was defined as a $2 \mathrm{~mm}$ indentation of the plaque surface towards the arterial wall.

\section{Statistical Analyses}

SPSS version 20 (SPSS Inc., Chicago, IL, USA) was used for the data analysis. MedCalc Statistical Software version 18 (MedCalc Software bvba, Ostend, Belgium) was used for building the graphics. Data are presented as (i) mean \pm standard deviation for continuous variables and (ii) counts with percentages for categorical variables. Normality of distribution for continuous variables was analysed using the Shapiro-Wilk test. Depending on the distribution pattern, independent samples t-test or Mann-Whitney U test was used for group comparisons of the continuous variables. Chi-square test or Fischer's Exact test was performed for the group comparisons of categorical variables as appropriate. Univariate and multivariate logistic regression analyses were used to assess the possible association among demographic, clinical, imaging findings, $\mathrm{CHA}_{2} \mathrm{DS}_{2}$-VASc scores and the presence of CAPs. Variables with $p<0.05$ in the univariate logistic regression were included in the multivariate logistic regression. Age, sex, HT, stroke, DM and CAD were included in the multivariate analysis regardless of their statistical significance in the univariate analysis. The statistical significance threshold in the multivariate analyses was adjusted using Bonferroni correction. Cochran-Armitage test was performed to test the trend between $\mathrm{CHA}_{2} \mathrm{DS}_{2}$-VASc scores and the prevalence of CAP. Unless otherwise stated, $p<0.05$ indicated statistical significance.

\section{Results}

\section{Patients Demographics}

The characteristics of all the 551 patients are shown in Table 1. Mean age was $55 \pm 18$ years, and $49.1 \%$ of the patients were men. The prevalence of AF was high (33.4\%). A total of 167 (30.3\%) patients had a recent or previous ischaemic stroke. Echocardiographic findings that were supposed to be a potential source of cardioembolism according to TOAST classification are also shown in Table 1. 


\section{Potential Cardiac Source of Embolism}

Fifty-two patients had LA/left atrial appendage (LAA) thrombi, three had left ventricular (LV) thrombi, 28 had a LV akinetic segment, three had an atrial myxoma, 97 had a diagnosis of dilated cardiomyopathy

Table 1. Demographic and echocardiographic characteristics of all patients

\begin{tabular}{|l|l|}
\hline Age \\
\hline Gender \\
\hline Female \\
\hline Male \\
\hline HT \\
\hline Stroke \\
\hline DM \\
\hline CAD \\
\hline Atrial fibrillation \\
\hline LVEF \\
\hline
\end{tabular}

LA diameter

Value $(n=551)$

$55 \pm 18$

LAA thrombus

LAA SEC

LAA velocity

CAP

$284(51.5 \%)$

$267(48.5 \%)$

$266(48.3 \%)$

$167(30.3 \%)$

$114(20.7 \%)$

$106(19.2 \%)$

$184(33.4 \%)$

$54 \pm 8$

$41 \pm 8$

$47(8.5 \%)$

$92(16.7 \%)$

$60 \pm 24$

$74(18.3 \%)$

PFO

$93(16.9 \%)$

ASD

$38(6.9 \%)$

ASA

$34(6.2 \%)$

LV thrombus

$3(0.5 \%)$

Dilated CM

$97(17.6 \%)$

Akinetic segment presence $28(5.1 \%)$

\begin{tabular}{l|l} 
LA thrombus & $5(0.9 \%)$
\end{tabular}

\begin{tabular}{l|l} 
Myxoma & $2(0.4 \%)$
\end{tabular}

\begin{tabular}{l|l} 
IE & $28(5.1 \%)$
\end{tabular}

MR

$443(80.4 \%)$

\section{MR grade}

Mild

Moderate

Moderate to severe

Severe

MS

$200(36.3 \%)$

$166(30.1 \%)$

$39(7.1 \%)$

$38(6.9 \%)$

$46(8.3 \%)$

MS grade

\begin{tabular}{|l|l|}
\hline Mild & $27(4.9 \%)$ \\
\hline Moderate & $16(2.9 \%)$ \\
\hline Severe & $3(0.5 \%)$ \\
\hline MVP & $19(3.4 \%)$ \\
\hline MAC & $7(1.3 \%)$ \\
\hline CHA $_{2}$ SS $_{2}$-VASc score & $2 \pm 2$ \\
\hline
\end{tabular}

HT: Hypertension, DM: diabetes mellitus, CAD: coronary artery disease, LVEF: left ventricular ejection fraction, LA: left atrial, LAA: left atrial appendage, SEC: spontaneous echo contrast, CAP: complex aortic plaque, PFO: patent foramen ovale, ASD: atrial septal defect, ASA: atrial septal aneurysm, LV: left ventricle, CM: cardiomyopathy, IE: infective endocarditis, MR: mitral regurgitation, MS: mitral stenosis, MVP: mitral valve prolapse, MAC: mitral annular calcification and 46 patients had a mitral stenosis with respect to the high risk for cardioembolism according to the TOAST classification. In addition, 184 patients had AF, of which 36 patients possessed a $\mathrm{CHA}_{2} \mathrm{DS}_{2}-\mathrm{VASC}$ score of 2, and CAP was detected in three of these 36 patients with AF. Therefore, the patients were deemed to have a high risk for future thromboembolism.

\section{Complex Aortic Plaques}

Patients were divided into two groups according to the presence or absence of CAP. CAP were detected in a total of 110 patients*. In univariate analyses, there was a statistically significant difference between the groups with respect to age $(p<0.001)$, HT $(p<0.001)$, CAD $(p<0.001)$, DM $(p=0.003)$ and AF $(p<0.001)$. Mean $\mathrm{CHA}_{2} \mathrm{DS}_{2}$-VASc score was significantly higher in patients with CAP $(2 \pm 1$ in patients without CAP and $4 \pm 1$ in patients with CAP, $p<0.001)$. After multivariate analyses, male sex $(p<0.001)$ and age $(p=0.001)$ were independently associated with the presence of CAP. As expected, $\mathrm{CHA}_{2} \mathrm{DS}_{2}$-VASC score was also independently associated with the presence of CAP $[p<0.001$, odds ratio (OR): 2.905 (1.906-4.428), confidence interval (CI): 95\%] (Table 2). Trend analyses of $\mathrm{CHA}_{2} \mathrm{DS}_{2}$-VASC score and presence of CAP demonstrated a significant linear relationship, which is depicted in Figures 1, 2 and 3.

\section{The Relationship Between Cardiac Rhythm and Complex Aortic Plaques}

Among the 551 patients, 184 patients had AF and AF patients had a higher percentage of CAP (28.1\% vs $54.5 \%)$. Although there was a significant difference in the univariate analyses $(p<0.001)$, AF was not independently associated with the presence of CAP in the multivariate analyses $(p=0.307)$. $\mathrm{CHA}_{2} \mathrm{DS}_{2}$-VASC score was also significantly associated with CAP both in the univariate and multivariate analyses $[\mathrm{p}<0.001$ and OR: 3.379 (1.848-6.179), Cl: 95\%]. Among the cases with sinus rhythm, 50 of them had CAPs. Although age, HT, DM, CAD, LV ejection fraction and $\mathrm{CHA}_{2} \mathrm{DS}_{2}$-VASC score were significant in the univariate analysis, only $\mathrm{CHA}_{2} \mathrm{DS}_{2}$-VASC score was independently associated with the presence of CAP after the multivariate analysis $[p<0.001,3.021$ (1.620-5.623), $\mathrm{Cl}$ : 95\%] (Table 3).

\section{P-value for trend $<0.001$}

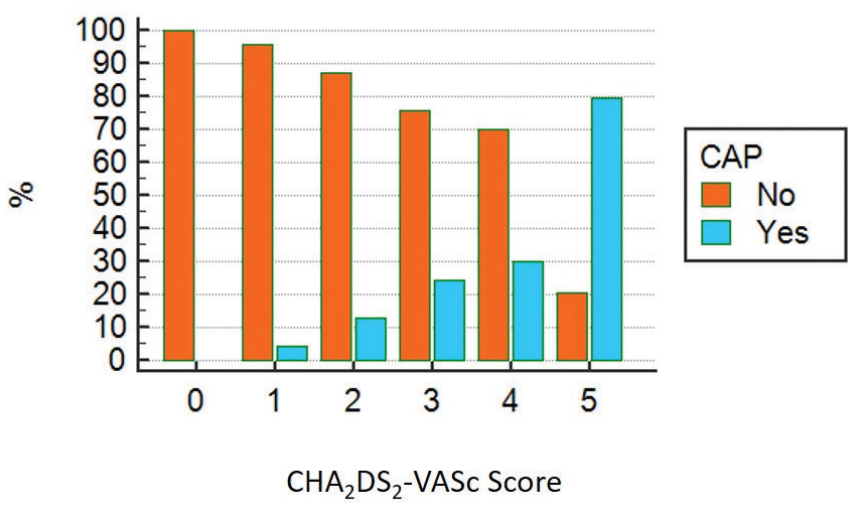

Figure 1. Trend analysis for $\mathrm{CHA}_{2} \mathrm{DS}_{2}$-VASC-VASc score and CAP in all patients CAP: complex aortic plaque 
Durmaz et al. $\mathrm{CHA}_{2} \mathrm{DS}_{2}$-VASC Score Beyond Atrial Fibrillation

Table 2. Group comparisons along with univariate and multivariate logistic regression analyses in all patients with or without complex aortic plaque

\begin{tabular}{|c|c|c|c|c|c|c|c|}
\hline & \multicolumn{3}{|c|}{ Group comparisons } & \multicolumn{2}{|c|}{ Univariate logistic regression } & \multicolumn{2}{|c|}{ Multivariate logistic regression } \\
\hline & $\begin{array}{l}\text { CAP- } \\
(n=441)\end{array}$ & $\begin{array}{l}\text { CAP+ } \\
(n=110)\end{array}$ & $\mathbf{p}$ & OR $(95 \% \mathrm{Cl})$ & $\mathbf{p}$ & OR $(95 \% \mathrm{CI})$ & $\mathbf{p}$ \\
\hline Age & $51 \pm 17$ & $71 \pm 10$ & $<0.001$ & 1.117 (1.091-1.144) & $<0.001$ & $1.056(1.023-1.090)$ & 0.001 \\
\hline Male & $209(47.4 \%)$ & $58(57.2 \%)$ & 0.338 & $1.238(0.815-1.881)$ & 0.317 & $3.008(1.526-5.391)$ & 0.001 \\
\hline HT & $180(40.8 \%)$ & $86(78.2 \%)$ & $<0.001$ & $5.196(3.181-8.487)$ & $<0.001$ & $0.609(0.279-1.331)$ & 0.214 \\
\hline Stroke & $131(29.7 \%)$ & $36(32.7 \%)$ & 0.563 & $1.151(0.736-1.801)$ & 0.537 & $0.425(0.188-0.960)$ & 0.039 \\
\hline DM & $76(17.2 \%)$ & $32(34.5 \%)$ & $<0.001$ & $2.535(1.593-4.032)$ & $<0.001$ & $0.533(0.260-1.094)$ & 0.086 \\
\hline CAD & $65(14.7 \%)$ & $41(37.3 \%)$ & $<0.001$ & 3.437 (2.153-5.487) & $<0.001$ & $0.409(0.193-0.869)$ & 0.020 \\
\hline $\mathrm{AF}$ & $124(28.1 \%)$ & $60(54.5 \%)$ & $<0.001$ & $3.068(1.998-4.711)$ & $<0.001$ & $0.697(0.348-1.394)$ & 0.307 \\
\hline LVEF & $55 \pm 7$ & $51 \pm 10$ & $<0.001$ & $0.946(0.924-0.968)$ & $<0.001$ & $1.015(0.972-1.059)$ & 0.506 \\
\hline LA diameter & $40 \pm 8$ & $43 \pm 6$ & $<0.001$ & $1.041(1.015-1.068)$ & 0.002 & $0.952(0.909-0.997)$ & 0.038 \\
\hline LAA thrombus & $28(6.3 \%)$ & $19(17.3 \%)$ & $<0.001$ & $3.080(1.648-5.755)$ & $<0.001$ & $2-202(0.881-5.503)$ & 0.091 \\
\hline LAA spontaneous echo contrast & $48(14.5 \%)$ & $27(36.5 \%)$ & $<0.001$ & $2.775(1.698-4.536)$ & $<0.001$ & $0.968(0.454-2.066)$ & 0.934 \\
\hline LAA velocity & $63 \pm 23$ & $50 \pm 23$ & $<0.001$ & $0.976(0.966-0.986)$ & $<0.001$ & $0.991(0.977-1.006)$ & 0.231 \\
\hline PFO & $81(18.4 \%)$ & $12(10.9 \%)$ & 0.065 & $0.544(0.285-1.038)$ & 0.065 & - & - \\
\hline ASD & $32(7.3 \%)$ & $6(5.5 \%)$ & 0.674 & $0.737(0.300-1.810)$ & 0.506 & - & - \\
\hline ASA & $30(6.8 \%)$ & $4(3.6 \%)$ & 0.272 & $0.517(0.178-1.500)$ & 0.225 & - & - \\
\hline LV thrombus & $2(0.5 \%)$ & $1(0.9 \%)$ & 0.488 & $2.014(0.181-22.412)$ & 0.569 & - & - \\
\hline Dilated CM & $68(15.4 \%)$ & $29(26.4 \%)$ & 0.011 & $1.964(1.195-3.227)$ & 0.008 & $2.003(0.835-4.803)$ & 0.120 \\
\hline Akinetic segment & $10(3.0 \%)$ & $5(6.8 \%)$ & 0.125 & $1.161(0.979-1.375)$ & 0.136 & - & - \\
\hline Akinetic segment number & $4 \pm 2$ & $5 \pm 3$ & 0.561 & 1.192 (0.716-1.983) & 0.500 & - & - \\
\hline LA thrombus & $4(0.9 \%)$ & $1(0.9 \%)$ & 0.998 & $1.002(0.111-9.058)$ & 0.998 & - & - \\
\hline LA SEC & $59(13.4 \%)$ & $33(30 \%)$ & $<0.001$ & & & & \\
\hline Myxoma & $2(0.5 \%)$ & 0 & 0.479 & - & 0.999 & - & - \\
\hline IE & $24(5.4 \%)$ & $4(3.6 \%)$ & 0.627 & $0.254(0.223-1.980)$ & $<0.001$ & $1.308(0.482-3.555)$ & 0.598 \\
\hline MR & $342(77.6 \%)$ & $101(91.8 \%)$ & $<0.001$ & 3.249 (1.585-6.658) & - & - & - \\
\hline MS & 37 (8.4\%) & $9(8.9 \%)$ & 0.944 & $0.973(0.455-2.081)$ & 0.944 & - & - \\
\hline MVP & $18(4.1 \%)$ & $1(0.9 \%)$ & 0.103 & $0.216(0.028-1.633)$ & 0.137 & - & - \\
\hline MAC & $5(1.1 \%)$ & $2(1.8 \%)$ & 0.566 & $1.615(0.309-8.436)$ & 0.570 & - & - \\
\hline $\mathrm{CHA}_{2} \mathrm{DS}_{2}$-VASc score & $2 \pm 1$ & $4 \pm 1$ & $<0.001$ & 2.537 (2.114-3.046) & $<0.001$ & 2.905 (1.906-4.428) & $<0.001$ \\
\hline
\end{tabular}

When the stroke patients were analysed according to presence of CAP, AF was found to be significantly more frequent in CAPs (+) patients.

\section{Discussion}

Our study demonstrated that the $\mathrm{CHA}_{2} \mathrm{DS}_{2}$-VASC score is strongly correlated with the presence of CAPs regardless of the underlying rhythm and that as the $\mathrm{CHA}_{2} \mathrm{DS}_{2}$-VASc score increased, the possibility of CAP detection also increased. After adjustment for atherosclerotic risk factors, LA abnormalities and cardiac rhythm, $\mathrm{CHA}_{2} \mathrm{DS}_{2}$-VASc score was still independently and significantly associated with the presence of CAPs. Moreover, trend analyses between $\mathrm{CHA}_{2} \mathrm{DS}_{2}$-VASC score and CAPs revealed that every 1 point increase in $\mathrm{CHA}_{2} \mathrm{DS}_{2}$-VASC score was significantly associated with an increased risk of the presence of CAPs. Although the $\mathrm{CHA}_{2} \mathrm{DS}_{2}$-VASc score was primarily developed to estimate the stroke risk in patients with NV-AF, current studies suggest that these scores might also predict the future stroke risk even in patients without AF. This may be explained by the fact that most of the parameters included in the $\mathrm{CHA}_{2} \mathrm{DS}_{2}$-VASc scoring system are also the risk factors for stroke (7). Therefore, concomitance of a high $\mathrm{CHA}_{2} \mathrm{DS}_{2}$-VASC score, CAPs and stroke should be expected and the findings of our study provide evidence for this concomitance.

Although the aetiology and treatment modalities of ischaemic stroke are well defined in the literature, the precise cause of the ischaemic event in a particular patient cannot be established in most stroke cases (8). The TOAST classification system divides strokes into five subgroups according to the cause: cardioembolism, large artery atherosclerosis, small-vessel occlusion, stroke of other determined aetiology and stroke of undetermined aetiology. Strokes have an undetermined aetiology 
P-value for trend $<0.001$

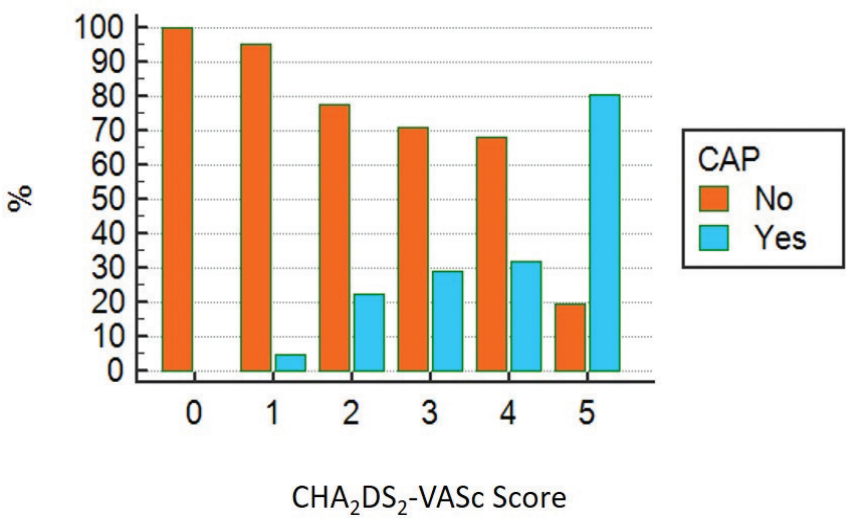

Figure 2. Trend analysis for $\mathrm{CHA}_{2} \mathrm{DS}_{2}$-VASC score and CAP in patients with atrial fibrillation

CAP: complex aortic plaque
$P$-value for trend $<0.001$

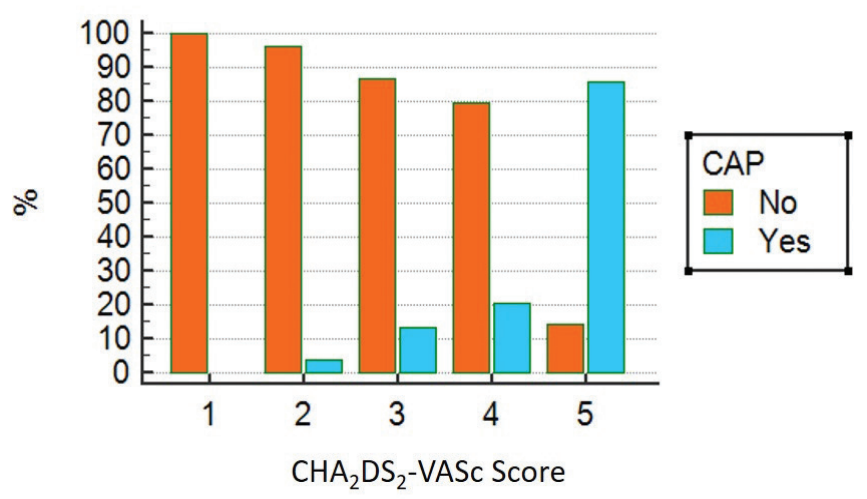

Figure 3. Trend analysis for $\mathrm{CHA}_{2} \mathrm{DS}_{2}-\mathrm{VASC}-\mathrm{VASC}$ score and CAP patients with stroke

CAP: Complex aortic plaque

Table 3. Group comparisons along with univariate and multivariate logistic regression analyses in patients with atrial fibrillation

\begin{tabular}{|c|c|c|c|c|c|c|c|}
\hline & \multicolumn{3}{|c|}{ Group comparisons } & \multicolumn{2}{|c|}{ Univariate logistic regression } & \multicolumn{2}{|c|}{ Multivariate logistic regression } \\
\hline & $\begin{array}{l}\text { AF+ \& CAP- } \\
(n=124)\end{array}$ & $\begin{array}{l}\mathrm{AF}+\& \mathrm{CAP}+ \\
(n=60)\end{array}$ & $\mathbf{p}$ & OR $(95 \% \mathrm{CI})$ & $\mathbf{p}$ & OR $(95 \% \mathrm{Cl})$ & $\mathrm{p}$ \\
\hline Male & $65(52.4 \%)$ & $33(55.0 \%)$ & 0.755 & $1.109(0.598-2.060)$ & 0.742 & 3.655 (1.453-9.199) & 0.006 \\
\hline HT & $80(64.5 \%)$ & $51(85.0 \%)$ & 0.005 & $3.117(1.403-6.925)$ & 0.005 & $0.530(0184-1.521)$ & 0.238 \\
\hline CAD & $36(29.0 \%)$ & $28(46.7 \%)$ & 0.021 & $2.139(1.130-4.050)$ & 0.020 & $0.518(0.181-1.484)$ & 0.221 \\
\hline LVEF & $52 \pm 9$ & $48 \pm 10$ & 0.016 & $0.985(0.955-1.015)$ & 0.327 & - & - \\
\hline LA diameter & $47 \pm 10$ & $46 \pm 7$ & 0.806 & $0.990(0.952-1.029)$ & 0.599 & - & - \\
\hline LAA thrombus & $23(18.5 \%)$ & $16(26.7 \%)$ & 0.249 & $1.597(0.770-3.313)$ & 0.209 & - & - \\
\hline ASD & $5(4 \%)$ & $1(1.7 \%)$ & 0.397 & $0.403(0.046-3.532)$ & 0.412 & - & - \\
\hline ASA & $6(4.8 \%)$ & $1(1.7 \%)$ & 0.292 & $0.333(0.039-2.833)$ & 0.314 & - & - \\
\hline LV thrombus & $2(1.6 \%)$ & 0 & 1.000 & - & - & - & - \\
\hline Dilated CM & $39(31.5 \%)$ & $19(31.7 \%)$ & 0.326 & $1.010(0.520-1.960)$ & 0.977 & - & - \\
\hline Akinetic segment & $7(7.4 \%)$ & $4(8.9 \%)$ & 0.747 & 0.968 (0.777-1.204) & 0.767 & - & - \\
\hline $\begin{array}{l}\text { Akinetic segment } \\
\text { diameter }\end{array}$ & $4 \pm 2$ & $5 \pm 3$ & 1.000 & $1.046(0.596-1.834)$ & 0.876 & - & - \\
\hline LA thrombus & $1(0.8 \%)$ & $1(1.7 \%)$ & 0.598 & $2.085(0.128-33.912)$ & 0.606 & - & - \\
\hline Myxoma & $1(0.8 \%)$ & 0 & 1.000 & - & - & - & - \\
\hline IE & 0 & 0 & - & - & - & - & - \\
\hline
\end{tabular}

HT: Hypertension, DM: diabetes mellitus, CAD: coronary artery disease, AF: atrial fibrillation, LVEF: left ventricular ejection fraction, LA: left atrium, LAA: left atrial appendage, SEC: spontaneous echo contrast, CAP: complex aortic plaque, PFO: patent foramen ovale, ASD: atrial septal defect, ASA: atrial septal aneurysm, LV: left ventricle, CM: cardiomyopathy, IE: infective endocarditis, MS: mitral stenosis, MR: mitral regurgitation, MVP: mitral valve prolapse, MAC: mitral annular calcification, OR: odds ratio , CI: confidence interval 
when the underlying cause cannot be established or more than one possible aetiologies are detected (1). In our study, we demonstrated that $39 \%$ of patients had at least two possible sources of embolism. Since the suggested strategy of treatment differs between TOAST groups, it is essential to precisely decide on the aetiology of the stroke. This scope of view is also valuable in patients with AF. Both the American College of Cardiology/American Heart Association and European Society of Cardiology $(\mathrm{ESC})(9,10)$ guidelines on the treatment of AF strongly recommend anticoagulation in patients with a higher stroke risk; however, it has been demonstrated in previous studies that statin is more beneficial than anticoagulation in patients with stroke due to the CAPs. Di Tullio et al. (11) compared acetylsalicylic acid therapy with anticoagulation in patients with a previous stroke and aortic arch atherosclerosis. There was no difference between the groups in terms of recurrent stroke and death; however, in that study, although statin therapy was not given routinely to all patients, statin treatment was associated with improved outcomes with respect to recurrent stroke and death. In the light of these previous studies and ours, it would be fairly reasonable to administer statin therapy in patients with stroke and CAP regardless of antithrombotic therapies.

Sugioka et al. (6) demonstrated that the CHADS score is associated with the presence of CAPs, which is concordant with our findings. Although the CHADS score was used to estimate the stroke risk, current guidelines recommend the use of the $\mathrm{CHA}_{2} \mathrm{DS}_{2}$-VASC score, which has a modestly higher predictive ability for stroke. Sugioka had also shown a higher prevalence of CAPs in patients with AF. Although in our study, the univariate analysis suggested the same in our study, after adjustment for possible confounders, multivariate analyses have revealed that there is no independent association between CAPs and cardiac rhythm. Since most of the risk factors of AF and atherosclerosis are overlapping, one can expect the co-occurrence of AF and CAPs. However, there is no evidence in the literature regarding the accelerated atherosclerosis in AF patients, which is the case in our study as well.

Yang et al. (12) have also demonstrated a significant relationship between $\mathrm{CHA}_{2} \mathrm{DS}_{2}$-VASC score and CAPs. In that study, they concluded that the concomitance of AF and CAP may increase the risk of stroke by different mechanisms. In our study, 60 out of 184 AF patients had CAPs (32.6\%), which eventually increased each patient's $\mathrm{CHA}_{2} \mathrm{DS}_{2}$-VASC score. There were 19 patients with a $\mathrm{CHA}_{2} \mathrm{DS}_{2}$-VASc score of 2. Among these patients, the score of two patients was 1 before the TEE examination and 1 point added as a result of the presence of CAPs, and consequently anticoagulation was indicated. Contrariwise to Yang et al. (12), there was a higher number of patients with CAP in our study (8.2\% vs 19.9\%). This may be explained by the higher $\mathrm{CHA}_{2} \mathrm{DS}_{2}$-VASC scores of the patients in our study (1.75 \pm 1.61 vs $2 \pm 2$ ). Beside the $\mathrm{CHA}_{2} \mathrm{DS}_{2}-$ VASC score, ESC considers the Turkish population as a very high-risk population for atherosclerosis (13). This may also explain the higher prevalence of CAP in our study.

\section{Impact on the Treatment Strategy}

In our study, 36 patients had AF with a $\mathrm{CHA}_{2} \mathrm{DS}_{2}$-VASc score of 2. Among these, three patients were considered as having an intermediate risk for stroke before the TEE examination; eventually, the presence of CAP increased their $\mathrm{CHA}_{2} \mathrm{DS}_{2}$-VASC score and anticoagulant therapy was finally indicated. Among those with a previous stroke, 38 patients had $\mathrm{AF}$ (22.7\%). If AF was considered as the primary underlying aetiology, anticoagulant therapy could be sufficient. However, 14 of 38 patients had CAP, which could well also be the obscure underlying aetiology. In conclusion, 14/167 (8.38\%) patients with stroke were detected to possess multiple sources of embolism, which requires both anticoagulant and statin therapies.

The major limitation of our study is its retrospective design. We included patients who underwent TEE examinations within the last 16 months; therefore, it did not reflect the effect of treatment on any patient. Another limitation of our study is that it as a single centre study, which is the reason for the relatively small number of patients with AF or stroke. Furthermore, we did not make mention of the clinical consequences of CAPs in our study population.

Since it was previously well defined in the literature that CAPs were associated with ischaemic stroke, patients with AF and high $\mathrm{CHA}_{2} \mathrm{DS}_{2}-\mathrm{VASC}$ scores need to be treated with statins in addition to the anticoagulant therapy. Future studies are needed to evaluate the value of statin therapy in patients with a high ischaemic stroke risk.

\section{Conclusion}

Although the $\mathrm{CHA}_{2} \mathrm{DS}_{2}$-VASc score predicts ischaemic stroke in patients with NV-AF, it is also useful for the prediction of CAPs, which are related to the ischaemic stroke in the literature.

\section{Ethics}

Ethics Committee Approval: The study was approved by the İstanbul University-Cerrahpaşa, Cerrahpaşa Faculty of Medicine Ethics Committee (decision no: 51436, date: 07.02.2018).

Informed Consent: Patients were included after their informed consent was obtained.

Peer-review: Externally peer-reviewed.

Authorship Contributions: Surgical and Medical Practices - E.D., C.E., E.Y., D.K., M.S.B.; Concept - E.D., B.K., B.Ko., U.R.; Design - E.D., B.K., C.E., B.Ko., D.K., M.S.B.; Data Collection or Processing - E.D., E.Y., U.R., Z.Ö.; Analysis or Interpretation - E.D., B.K.A., U.R., M.S.B., Z.Ö.; Literature Search - E.D., C.E., B.K.A., B.Ko., E.Y., Z.Ö.; Writing - E.D., B.K., B.K.A., D.K.

Conflict of Interest: No conflict of interest was declared by the authors.

Financial Disclosure: The authors declared that this study received no financial support.

\section{References}

1. Adams HP, Bendixen BH, Kappelle LJ, Biller J, Love BB, Gordon DL, et al. Classification of subtype of acute ischemic stroke. Definitions for use in a multicenter clinical trial. TOAST. Trial of Org 10172 in Acute Stroke Treatment. Stroke 1993; 24: 35-41.

2. Lip GYH, Nieuwlaat R, Pisters R, Lane DA, Crijns HJGM. Refining clinical risk stratification for predicting stroke and thromboembolism in atrial fibrillation using a novel risk factor-based approach. Chest 2010; 137: 263-72.

3. Melgaard L, Gorst-Rasmussen A, Lane DA, Rasmussen LH, Larsen TB, Lip $\mathrm{GYH}$. Assessment of the $\mathrm{CHA}_{2} \mathrm{DS}_{2}$-VASC score in predicting ischemic stroke, 
thromboembolism, and death in patients with heart failure with and without atrial fibrillation. JAMA 2015; 314: 1030.

4. Mitchell LB, Southern DA, Galbraith D, Ghali WA, Knudtson M, Wilton SB, et al. Prediction of stroke or TIA in patients without atrial fibrillation using CHADS 2 and CHA 2 DS 2 -VASC scores. Heart 2014; 100: 1524-30.

5. Reers S, Agdirlioglu T, Kellner M, Borowski M, Thiele H, Waltenberger J, et al. Incidence of left atrial abnormalities under treatment with dabigatran, rivaroxaban, and vitamin K antagonists. Eur J Med Res 2016; 21:41.

6. Sugioka K, Fujita S, Iwata S, Ito A, Matsumura Y, Hanatani A, et al. Relationship between CHADS2 score and complex aortic plaques by transesophageal echocardiography in patients with nonvalvular atrial fibrillation. Ultrasound Med Biol 2014; 40: 2358-64.

7. Grau AJ, Weimar C, Buggle F, Heinrich A, Goertler M, Neumaier S, et al. Risk factors, outcome, and treatment in subtypes of ischemic stroke: the German stroke data bank. Stroke 2001; 32: 2559-66.

8. Sacco RL, Adams R, Albers G, Alberts MJ, Benavente O, Furie K, et al. Guidelines for prevention of stroke in patients with ischemic stroke or transient ischemic attack. Circulation 2006; 113: e409-49.
9. Kirchhof P, Benussi S, Kotecha D, Ahlsson A, Atar D, Casadei B, et al. 2016 ESC Guidelines for the management of atrial fibrillation developed in collaboration with EACTS. Eur Heart J 2016; 37: 2893-962.

10. January CT, Wann LS, Alpert JS, Calkins H, Cigarroa JE, Cleveland Jr JC, et al. 2014 AHA/ACC/HRS Guideline for the Management of Patients With Atrial Fibrillation: A Report of the American College of Cardiology/American Heart Association Task Force on Practice Guidelines and the Heart Rhythm Society. J Am Coll Cardiol 2014; 64: e1-76.

11. Di Tullio MR, Russo C, Jin Z, Sacco RL, Mohr JP, Homma S. Aortic arch plaques and risk of recurrent stroke and death. Circulation 2009; 119: 2376-82.

12. Yang PS, Kim TH, Uhm JS, Kim JY, Joung B, Lee MH, et al. Clinical characteristics of complex aortic plaque in patients with non-valvular atrial fibrillation. Int J Cardiol 2017; 230: 85-90.

13. Piepoli MF, Hoes AW, Agewall S, Albus C, Brotons C, Catapano AL, et al. 2016 European Guidelines on cardiovascular disease prevention in clinical practice. Eur Heart J 2016; 37: 2315-81. 